\title{
PHENOTYPICAL CHARACTERIZATION AND ADHESIN IDENTIFICATION IN ESCHERICHIA COLI STRAINS ISOLATED FROM DOGS WITH URINARY TRACT INFECTIONS
}

\author{
Renato Pariz Maluta ${ }^{1}$, Ariel Eurides Stella ${ }^{2}$, Kátia Riccardi ${ }^{1}$, Everlon Cid Rigobelo ${ }^{3}$, José Moacir Marin ${ }^{4}$, Marileda \\ Bonafim Carvalho', Fernando Antonio de Ávila ${ }^{1}$
}

${ }^{1}$ Faculdade de Ciências Agrárias e Veterinárias, Universidade Estadual Paulista, Jaboticabal, SP, Brasil; ${ }^{2}$ Universidade Federal de Goiás, Campus Jataí, Unidade Jatobá, Jataí, GO, Brasil; ${ }^{3}$ Unidade Experimental de Dracena, Universidade Estadual Paulista, Dracena, SP, Brasil; ${ }^{4}$ Faculdade de Odontologia de Ribeirão Preto, Universidade de São Paulo, Ribeirão Preto, SP, Brasil.

Submitted: February 15, 2011; Returned to authors for corrections: June 21, 2011; Approved: August 30, 2011.

\begin{abstract}
Pathogenic strains of Escherichia coli are the most common bacteria associated with urinary tract infections in both humans and companion animals. Standard biochemical tests may be useful in demonstrating detailed phenotypical characteristics of these strains. Thirteen strains of E. coli isolated from dogs with UTIs were submitted to biochemical tests, serotyping for $\mathrm{O}$ and $\mathrm{H}$ antigens and antimicrobial resistance testing. Furthermore, the presence of $p a p C, s f a$, and $a f a$ genes was evaluated by PCR, and genetic relationships were established using enterobacterial repetitive intergenic consensus PCR (ERIC-PCR). The antimicrobial that showed the highest resistance rate among the isolates was nalidixic acid (76.9\%), followed by cephalotin (69.2\%), sulfamethoxazole + trimethoprim (61.5\%), tetracycline (61.5\%), streptomycin $(53.8 \%)$, ciprofloxacin $(53.8 \%)$, ampicillin $(46.2 \%)$, gentamicin $(30.8 \%)$ and chloramphenicol (23.1\%). No isolate was resistant either to meropenem or nitrofurantoin. Among the five clusters that were identified using ERIC-PCR, one cluster (A) had only one strain, which belonged to a serotype with zoonotic potential $(\mathrm{O} 6: \mathrm{H} 31)$ and showed the genes $p a p \mathrm{C}+, s f a+, a f a-$. Strains with the genes $p a p \mathrm{C}-, s f a+, a f a-$ were found in two other clusters (C and D), whereas all strains in clusters B and E possessed papC-, sfa-, afa- genes. Sucrose and raffinose phenotypic tests showed some ability in discriminating clusters A, B and C from clusters D and E.
\end{abstract}

Key words: biomarkers, biotyping, ERIC-PCR, UPEC

\section{INTRODUCTION}

Escherichia coli is the most common pathogen associated with urinary tract infection (UTI) $(5,10,30)$. E. coli that are associated with UTI are commonly named uropathogenic isolates (UPEC), although there is evidence that different pathotypes may be related to UTI (19). The term UPEC may not be entirely correct, because clones and virulence factors are not syndrome- specific (23). Johnson et al. (11) reported that pathogenic E. coli strains may pose a risk to either humans or

*Corresponding Author. Mailing address: Departamento de Patologia Veterinária, Faculdade de Ciências Agrárias e Veterinárias, Universidade Estadual Paulista, Via de Acesso Prof. Paulo Donato Castellane s/n, Jaboticabal, SP, Brasil - CEP: 14884-900.; Tel.: (55) (16) 3209-2652 Fax: (55) (16) 3209-2956.; E-mail: maluta@gmail.com 
animals. Humans and dogs could acquire pathogenic E. coli strains from one another.

Surface virulence factors of UPEC include several adhesins that are primarily fimbrial (5). These fimbriae recognize receptors of the host cell surface and may improve bacterial adhesion. The $\mathrm{P}$ fimbria, which is encoded by the pap gene, is antigenically diverse due to peptide sequence variability within PapA $(8,14)$. The $S$ fimbria (encoded by $s f a$ genes) has also been implicated in the process of UTI. This adhesin binds to epithelial and endothelial cell lines derived from the human urinary tract (5). Factor Afa (encoded by afa gene) is an afimbrial adhesin, and together with $\mathrm{P}$ and $\mathrm{S}$ fimbriae, have been epidemiologically related to $E$. coli strains that cause UTI in humans and pets (4).

In Brazil, the involvement of adhesins, toxins and other virulence factors of $E$. coli isolated of urinary infections, pyometra and feces from dogs have been described previously $(2,26,28)$

Although molecular diagnostic techniques are becoming more accessible, many laboratories use phenotypical characterizations for routine diagnoses. Serotyping remains an important method for categorizing UPEC, because these strains represent a restrict number of $\mathrm{O}$ groups $(\mathrm{O} 1, \mathrm{O} 2, \mathrm{O} 4, \mathrm{O} 6, \mathrm{O} 7$, O18ac, O75, O16 and O15) and $\mathrm{K}$ groups (K1, K2, K3, K5, K12 and K13) (23).

Biotyping, used together with serotyping, may be useful for strain differentiation in situations where patients are suffering recurrent infections, such as reinfections (with different organisms) or relapses (with the same organism) (9). In these situations, phenotypical characteristics determined using standard biochemical tests may be useful biomarkers.

The presence of certain virulence genes may be accessory in order to elucidate if $E$. coli isolates may be harmful. For instance, an $E$. coli isolate previously detected in humans with neonatal meningitis contained the gene sfa (11). Also, a previous work showed that genes papC and $s f a$ are associated with $E$. coli from urinary samples when compared to rectal samples of dogs with UTI (12)

The goal of this work was to compare potential phenotypic markers, presence of adhesins related to E. coli infection and clusters of isolates, using ERIC-PCR, in strains obtained from the urinary tract of dogs with UTIs, as well as the zonotic potential of isolates.

\section{MATERIALS AND METHODS}

\section{Samples}

Thirteen strains of E. coli were isolated from urine samples (collected aseptically through cystocentesis) from dogs that were diagnosed with UTIs and were being attended at UNESP - Univ Estadual Paulista, Jaboticabal, SP, Veterinary Hospital. The strains were identified in the microbiology laboratory of the same university using MacConkey agar, blood agar and IMViC tests. Strain stocks were maintained on agar slants held at $4{ }^{\circ} \mathrm{C}$. To determine their physiological characteristics, strains were inoculated in TSI agar and were submitted to several biochemical tests (indole production, methyl red, Voges-Proskauer, citrate, malonate, urease, lysine decarboxylase, arginine dihydrolase, ornitine decarboxylase, $\beta$ galactosidase, phenylalanine deaminase, gelatinase, glucose, mannitol, inositol, sorbitol, sucrose, melibiose, dulcitol, xylose, maltose, raffinose, trehalose, mannose, fructose and motility) $(15,18)$. The strains were then sent to a reference laboratory (Instituto Adolfo Lutz, São Paulo, Brazil) for serotype identification using sera against somatic $(\mathrm{O})$ and flagellar $(\mathrm{H})$ antigens (21).

\section{DNA templates}

DNA templates were obtained using the thermal lysis procedure of Wani et al. (29) with slight modifications. Bacterial strains were grown overnight in brain heart infusion (BHI) media at $35{ }^{\circ} \mathrm{C}$, were pelleted by centrifugation at $12,000 \mathrm{x} \mathrm{g}$ for $1 \mathrm{~min}$, resuspended in $200 \mu \mathrm{l}$ of sterile distilled water and were lysed by boiling for $10 \mathrm{~min}$. Lysates were 
centrifuged as described above, and $150 \mu \mathrm{l}$ of the supernatants were recovered. These supernatants were used as templates for PCR and ERIC-PCR.

\section{PCR amplification of virulence genes}

Multiplex PCR was used to detect papC, sfa and $a f a$ genes (17) in all E. coli strains except one (EC15).

\section{ERIC-PCR}

The E. coli strains were subjected to ERIC-PCR reactions with the primers ERIC1R (5'-ATGTAAGCTCCTGGGGATTC AC-3') and ERIC2 (5'-AAGTAAGTGACTGGGGTGAGCG$\left.3^{\prime}\right)$ (27). Each ERIC-PCR reaction was performed in a total volume of $20 \mu \mathrm{L}$ with the following components: $4 \mu \mathrm{L}$ of DNA template, $2 \mu \mathrm{L}(10 \mathrm{pM})$ of both primers, $1 \mu \mathrm{L}$ of a dNTP mixture (10 mM each), $4 \mu \mathrm{L}$ of buffer solution, $3 \mu \mathrm{L}$ of $25 \mathrm{mM}$ $\mathrm{MgCl}_{2}$ and 1 unit of Taq DNA polymerase (Fermentas, Europe). The PCR amplification thermal profile was based on a previous report (24) with minor modifications: initial denaturation $94{ }^{\circ} \mathrm{C}$ for $5 \mathrm{~min}$; followed by 30 cycles of denaturation $\left(94{ }^{\circ} \mathrm{C}, 30 \mathrm{~s}\right)$, annealing $\left(52{ }^{\circ} \mathrm{C}, 45 \mathrm{~s}\right)$ and extension $\left(72{ }^{\circ} \mathrm{C}, 1 \mathrm{~min}\right)$ with a final extension step $\left(72^{\circ} \mathrm{C}, 7\right.$ min). Ten microliters of each reaction was then analyzed by electrophoresis using a $1.5 \%$ gel stained with ethidium bromide. To perform ERIC fingerprint analyses, a binary matrix of band presence or absence was used in UPGMA (Unweighted Pair Group Method for Arithmetic Averages) clustering based on Dice's correlation coefficients using the program Freetree (version 0.9.1.50). A dendrogram of the strains was visualized using TreeView (version 1.30). Dendrogram clustering was done empirically.

\section{Antimicrobial resistance testing and multiple antibiotic resistance (MAR) index}

All E. coli isolates were subjected to disk diffusion tests using Muller-Hinton agar with the following antimicrobial compounds: ampicillin (10 $\mu \mathrm{g})$, streptomycin $(10 \mu \mathrm{g})$, gentamicin $(10 \mu \mathrm{g})$, cephalotin $(30 \mu \mathrm{g})$, nalidixic acid (30 ug), chloramphenicol $\quad(30 \mu \mathrm{g}), \quad$ ciprofloxacin $\quad(5 \mu \mathrm{g})$, sulfamethoxazole + trimethoprim $(25 \mu \mathrm{g})$, meropenem $(10 \mu \mathrm{g})$, nitrofurantoin $(300 \mu \mathrm{g})$ and tetracycline $(30 \mu \mathrm{g})$. The results from disk diffusion tests were compared to published guidelines (1). This test was used to calculate the multiple antibiotic resistance index (MAR) (16).

\section{Statistics}

The specificities, sensitivities and likelihood ratios (LRs) were calculated with the software MedCalc 11.5.1.

\section{RESULTS}

Table 1 summarizes the results of biochemical tests, serotyping and the calculated MAR index of all strains. Strain EC18 yielded an inconclusive result for arginine dihydrolase because a positive or negative result could not be determined based on the reaction color. Strains EC4 and EC13 showed a weak positive reaction for dulcitol. All strains were positive for the following tests: indole production, methyl red, $\beta$ galactosidase, glucose, mannitol, sorbitol, melibiose, maltose, trehalose, mannose and fructose. On the other hand, all strains were negative for Voges-Proskauer (VP), citrate production, urease, phenylalanine deaminase, gelatinase, inositol and malonate tests. Table 1 also includes PCR results for papC, sfa and $a f a$ for all strains except one (EC15).

A dendrogram based on ERIC-PCR results had five clusters (A, B, C, D and E), which are shown in Figure 1 and Table 1. The antimicrobial that showed the highest resistance rate among the isolates was nalidixic acid (76.9\%), followed by cephalotin (69.2\%), sulfamethoxazole + trimethoprim $(61.5 \%)$, tetracycline $(61.5 \%)$, streptomycin $(53.8 \%)$, ciprofloxacin (53.8\%), ampicillin (46.2\%), gentamicin (30.8\%) and chloramphenicol $(23.1 \%)$. No isolate was resistant either to meropenem or nitrofurantoin.

The specificity and sensitivity tests were performed with all substrates that showed at least one different result among the isolates, except dulcitol that was not evaluated due to it 
weak reactions. In order discriminate clusters A, B and C from clusters D and E, sucrose showed a specificity of $100 \%$, a sensitivity of $87.5 \%$ and a negative LR of 0.125 . Raffinose had a specificity of $71.4 \%$, a sensitivity of $83.3 \%$, a positive LR of 2.917 and a negative LR of 0.233 . The remaining substrates demonstrated specificity and/or sensibility smaller than $70 \%$.

Table 1. Genetic and phenotypic characteristics of Escherichia coli strains isolated from dogs with urinary tract infections*

\begin{tabular}{|c|c|c|c|c|c|c|c|c|c|c|c|c|c|c|}
\hline & $\begin{array}{l}\text { Cluster } \\
\text { (ERIC-PCR) }\end{array}$ & $\mathbf{A}$ & B & B & B & $\mathbf{C}$ & $\mathbf{C}$ & $\mathbf{C}$ & D & D & D & $\mathbf{E}$ & $\mathbf{E}$ & $\mathbf{E}$ \\
\hline & Strain code & EC18 & EC14 & EC10 & EC6 & EC16 & EC19 & EC8 & EC13 & EC11 & EC4 & EC12 & EC15 & EC7 \\
\hline & MAR index & 0.18 & 0.64 & 0.73 & 0.09 & 0.73 & 0.73 & 0.73 & 0.18 & 0.09 & 0.18 & 0.55 & 0.09 & 0.73 \\
\hline & $\begin{array}{l}\text { Serotype } \\
\text { Adhesins }\end{array}$ & $\begin{array}{c}\text { O6:H31 } \\
\text { sfa+ } \\
\text { papC+ } \\
\text { afa- }\end{array}$ & $\begin{array}{c}\text { ONT:H- } \\
\text { sfa- } \\
\text { papC } \\
\text {-afa- }\end{array}$ & $\begin{array}{c}\text { OR:HNT } \\
\text { sfa- } \\
\text { papC- } \\
\text { afa- }\end{array}$ & $\begin{array}{c}\text { O9:H11 } \\
\text { sfa- } \\
\text { papC- } \\
\text { afa- }\end{array}$ & $\begin{array}{c}\text { ONT:HR } \\
\text { sfa- } \\
\text { papC- } \\
\text { afa- }\end{array}$ & $\begin{array}{c}\text { OR:H34 } \\
\text { sfa- } \\
\text { papC- } \\
\text { afa- }\end{array}$ & $\begin{array}{c}\text { OR:H1 } \\
\text { sfa+ } \\
\text { papC- } \\
\text { afa- }\end{array}$ & $\begin{array}{c}\text { OR:H1 } \\
\text { sfa+ } \\
\text { papC- } \\
\text { afa- }\end{array}$ & $\begin{array}{c}\text { OR:H1 } \\
\text { sfa+ } \\
\text { papC- } \\
\text { afa- }\end{array}$ & $\begin{array}{c}\text { OR:H1 } \\
\text { sfa+ } \\
\text { papC- } \\
\text { afa- }\end{array}$ & $\begin{array}{c}\text { O1:H23 } \\
\text { sfa- } \\
\text { papC- } \\
\text { afa- }\end{array}$ & $\begin{array}{c}\text { O1:H36 } \\
\text { NA }\end{array}$ & $\begin{array}{c}\text { O10:HNT } \\
\text { sfa- } \\
\text { papC- } \\
\text { afa- } \\
\end{array}$ \\
\hline \multirow{3}{*}{$\begin{array}{c}\text { Enzymatic } \\
\text { activity }\end{array}$} & Lysine decarboxylase & - & - & + & + & + & + & + & + & + & + & + & + & + \\
\hline & Arginine dihydrolase & IN & + & + & + & - & + & - & - & - & - & + & + & - \\
\hline & Ornitine decarboxylase & + & - & - & + & - & + & + & + & + & + & + & + & + \\
\hline \multirow{5}{*}{$\begin{array}{c}\text { Acid } \\
\text { production }\end{array}$} & Sucrose & + & + & + & + & + & + & + & - & - & - & - & + & - \\
\hline & Melibiose & + & + & + & + & + & + & + & + & + & + & + & + & + \\
\hline & Dulcitol & + & - & - & - & - & - & - & WR & + & WR & + & - & + \\
\hline & Xylose & + & + & + & + & + & + & + & + & - & + & + & + & + \\
\hline & Raffinose & + & + & - & + & + & + & - & - & - & - & - & + & - \\
\hline Other & Motility & + & - & + & + & - & + & + & + & + & + & + & + & + \\
\hline
\end{tabular}

NA - Not available, IN - Inconclusive, WR - Weak reaction

*For the remaining biochemical tests, see the results section.
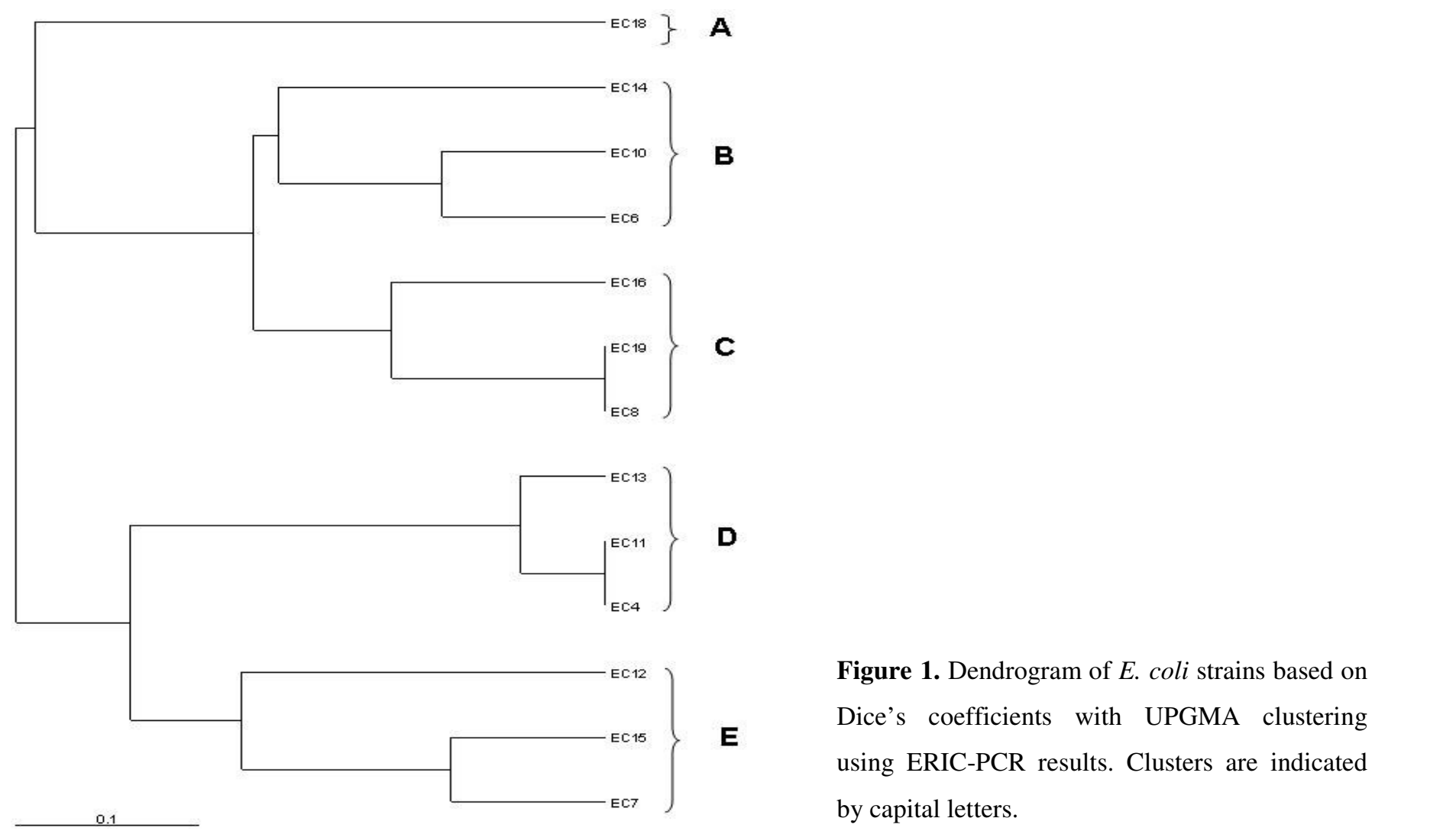

Figure 1. Dendrogram of E. coli strains based on Dice's coefficients with UPGMA clustering using ERIC-PCR results. Clusters are indicated by capital letters. 


\section{DISCUSSION}

Several phenotypic properties and adhesins related to infection by $E$. coli isolated from dogs with UTI were investigated in the current study, and our strains were grouped into five genetically related clusters.

EC18 was the sole strain comprising cluster A, and it was the only strain with the presence of genes $s f a+p a p \mathrm{C}+a f a-$. EC18 and EC14 (cluster B) were the only strains that were negative in tests for lysine decarboxylase activity. In a previous study by Yuri et al. (30), E. coli strains containing pap, sfa, hly and cnfl showed similar characteristics to those of strains that cause human UTI. Strain EC18 belongs to the serotype O6:H31, and according to Johnson et al. (13), this serotype has strong molecular evidence for zoonotic potential. This serotype was previously isolated from humans with UTI in Brazil (6). The identification of same serotype $(\mathrm{O} 6: \mathrm{H} 31)$ in the present study indicates the risk of transmission of pathogenic $E$. coli from dogs with UTI to humans, due to close contact between peoples and this companion animal.

Cluster B contained strains with different serotypes, although all of them lacked the targeted genes. The serogroup of strain EC6 (O9) was also found in dogs with UTI and in humans with cystitis and bacteremia (11). These strains isolated from humans with bacteremia did not possess papC and $s f a$ genes as strain EC6.

Of the three strains in cluster $\mathrm{C}$, one had the genotype $s f a+$, papC-, afa- (EC8) and was the only strain with this genotype that did not belong to cluster D. All strains in cluster $\mathrm{D}$ had the same genotype (sfa+, papC-, afa-) and did not ferment sucrose and raffinose. Strains that have the gene sfa are reported to generally also have the gene pap $(7,11,30)$. However, some strains with $s f a$ do not possess pap, such as strain O83:K1:H1 isolated from humans with neonatal meningitis (11) and isolates from feces of dogs and cats (30).

E. coli serogroup $\mathrm{O} 1$ have been described in human UTI $(10,23)$ Among the 13 canine strains studied, two isolates from cluster E (EC 12 and EC 15) belonged to the same serogroup.
However, these strains did not possess any virulence factors studied.

Strain EC15 showed several differences with respect to sucrose, raffinose and the MAR index when compared to the other strains of this cluster (EC7 and EC12). We hypothesize that these results were due to different phenotypic expression.

In a previous work with $E$. coli from canine pyometra, the resistance to cephalotin was similar $(69.2 \%)$ to this work, but the resistance to ampicillin $(68.9 \%)$ was higher, while resistances to tetracycline $(32.5 \%)$, gentamicin $(15.2 \%)$ and chloramphenicol $(7.9 \%)$ were lower (2). However, in other work with E. coli from dogs with UTI, the resistance to sulfamethoxazole + trimethoprim was similar (64.7\%) but resistance to ampicillin was higher $(56.8 \%)$ and resistances to ciprofloxacin (31.4\%) and gentamicin (17.6\%) were lower (25). The fact that all isolates were not resistant to meropenem is interesting, since this is one of the few drugs that can be used to attack infections due to extended-spectrum $\beta$-lactamaseproducing Enterobacteriaceae (ESBLs) (22).

Likelihoods ratios can be positive (greater than 1) or negative (between 0 and 1). LR equal 1 lack diagnostic value (20). Since the negative LR of sucrose was closer to 0 , it may have diagnostic potential. After sucrose, raffinose had the better LR. Previous studies showed good typing results with raffinose (3, 9). Furthermore, sucrose and raffinose fermentation can show correlation (3). Clusters C and D belong to the same branch in the dendrogram, whereas clusters A, B and $\mathrm{C}$ belong to a different branch; therefore, it is thought that $\mathrm{C}$ and $\mathrm{D}$ are genetically closer.

The present study revealed the involvement of some adhesins in pathogenicity of $E$. coli strains isolated from dogs with urinary tract infection, and that some biochemical markers will have the potential to differentiate between $E$. coli isolates (originating from canine UTI) that are genetically clustered. The results also emphasizes the zoonotic potential of some serotypes of E. coli strains isolated from UTI in dogs studied, due to involvement of same serotypes in human urinary infections. 


\section{ACKNOWLEDGEMENTS}

We thank the Fundação para o desenvolvimento da UNESP (FUNDUNESP - grant no. 01198/08-DFP) for financial support of this work. R.P. Maluta and A. E. Stella held scholarships from the Coordenação de Aperfeiçoamento de Pessoal de Nível Superior (CAPES) and K. Riccardi held a scholarship from the National Council for Scientific and Technological Development (CNPq) during the development of this research. We also thank the Instituto Adolfo Lutz staff for serotyping the isolates of this work.

\section{REFERENCES}

1. Clinical and Laboratory Standard Institute. (2009). Performance standards for antimicrobial disk susceptibility tests, CLSI document M02-A10. Clinical and Laboratory Standard Institute (CLSI), Wayne.

2. Coggan, J.A.; Melville, P.A.; Oliveira, C.M.; Faustino, M.; Moreno, A.M.; Benites, N.R. (2008). Microbiological and histopathological aspects of canine pyometra. Braz. J. Microbiol. 39477-483.

3. Crichton, P.B.; Old, D.C. (1979). Biotyping of Escherichia coli. J. Med. Microbiol. 12 (4), 473-486.

4. Donnenberg, M.S.; Rodney, A.W. (1996). Virulence determinants of uropathogenic Escherichia coli. In: Mobley, H.L.T., Warren, J.W. (eds). Urinary Tract Infections, Molecular Pathogenesis and Clinical Management. ASM Press, Washington, DC, p. 135-174.

5. Emody, L.; Kerényi, M.; Nagy, G. (2003). Virulence factors of uropathogenic Escherichia coli. Int. J. Antimicrob. Agents 22 (Supplement 2), 29-33.

6. $\quad$ Esparis, C.M.; Teixeira, L.M.; Irino, K.; Gil, P.F.; Almeida, M.M.T.B.; Lopes, G.S.; Bravo, V.L.R.; Pacheco, R.S.; Regua-Mangia, A.H. (2006). Aspectos biológicos e moleculares de amostras uropatogênicas de Escherichia coli isoladas na Cidade do Rio de Janeiro. Rev. Soc. Bras. Med. Trop. 39573-576.

7. Féria, C.; Machado, J.; Correia, J.D.; Gonçalves, J.; Gaastra, W. (2001). Virulence genes and $\mathrm{P}$ fimbriae PapA subunit diversity in canine and feline uropathogenic Escherichia coli. Vet. Microbiol. 82 (1), 81-89.

8. Garcia, E.; Bergmans, H.E.N.; van der Zeijst, B.A.M.; Gaastra, W. (1992). Nucleotide sequences of the major subunits of F9 and F12 fimbriae of uropathogenic Escherichia coli. Microb. Pathog. 13 (2), 161166.

9. Gargan, R.; Brumfitt, W.; Hamilton-Miller, J.M. (1982). A concise biotyping system for differentiating strains of Escherichia coli. J. Clin.
Pathol. 35 (12), 1366-1369.

10. Gyles, C.L.; Fairbrother, J.M. (2010). Escherichia coli. In: Gyles, C.L., Prescott, J.F., Songer, G., Thoen, C.O. (eds). Pathogenesis of bacterial infections in animals. Wiley-Blackwell, New York, p. 267-308.

11. Johnson, J.R.; Stell, A.L.; Delavari, P.; Murray, A.C.; Kuskowski, M.; Gaastra, W. (2001). Phylogenetic and Pathotypic Similarities between Escherichia coli Isolates from Urinary Tract Infections in Dogs and Extraintestinal Infections in Humans. J. Infect. Dis. 183 (6), 897-906.

12. Johnson, J.R.; Kaster, N.; Kuskowski, M.A.; Ling, G.V. (2003). Identification of Urovirulence Traits in Escherichia coli by Comparison of Urinary and Rectal E. coli Isolates from Dogs with Urinary Tract Infection. J. Clin. Microbiol. 41 (1), 337-345.

13. Johnson, J.R.; Johnston, B.; Clabots, C.R.; Kuskowski, M.A.; Roberts, E.; DebRoy, C. (2008). Virulence Genotypes and Phylogenetic Background of Escherichia coli Serogroup O6 Isolates from Humans, Dogs, and Cats. J. Clin. Microbiol. 46 (2), 417-422.

14. Klemm, P.; Orskov, I.; Orskov, F. (1982). F7 and type 1-like fimbriae from three Escherichia coli strains isolated from urinary tract infections: protein chemical and immunological aspects. Infect. Immun. 36 (2), $462-$ 468.

15. Koneman, E.W. (2005). Koneman's Color Atlas and Textbook of Diagnostic Microbiology. Williams \& Wilkins, Baltimore.

16. Krumperman, P.H. (1983). Multiple antibiotic resistance indexing of Escherichia coli to identify high-risk sources of fecal contamination of foods. Appl. Environ. Microbiol. 46 (1), 165-170.

17. Le Bouguenec, C.; Archambaud, M.; Labigne, A. (1992). Rapid and specific detection of the pap, afa, and $s f a$ adhesin-encoding operons in uropathogenic Escherichia coli strains by polymerase chain reaction. $J$. Clin. Microbiol. 30 (5), 1189-1193.

18. Mac Faddin, J.F. (1976). Biochemical tests for identification of medical bacteria Williams \& Wilkins, Baltimore.

19. Marrs, C.F.; Zhang, L.; Foxman, B. (2005). Escherichia coli mediated urinary tract infections: Are there distinct uropathogenic E. coli (UPEC) pathotypes? FEMS Microbiol. Lett. 252 (2), 183-190.

20. McGee, S. (2002). Simplifying Likelihood Ratios. J. Gen. Intern. Med. 17 (8), 647-650.

21. Orskov, F.; Orskov, I. (1984). Serotyping of Escherichia coli. Methods Microbiol. 1443 - 112.

22. Pitout, J.D.D.; Laupland, K.B. (2008). Extended-spectrum [beta]lactamase-producing Enterobacteriaceae: an emerging public-health concern. The Lancet Infectious Diseases 8 (3), 159-166.

23. Scheutz, F.; Strockbine, N.A. (2005). Genus I. Escherichia Castellani and Chalmers 1919, $941 \mathrm{~T}^{\mathrm{AL}}$. In: Garrity, G., Brenner, D.J., Krieg, N.R., Staley, J.R. (eds). Bergey's Manual of Systematic Bacteriology, The Proteobacteria, Part B: The Gammaproteobacteria. Springer, New York, p. 607-625. 
24. Silveira, W.D.; Ferreira, A.; Lancellotti, M.; Barbosa, I.A.G.C.D.; Leite, D.S.; de Castro, A.F.P.; Brocchi, M. (2002). Clonal relationships among avian Escherichia coli isolates determined by enterobacterial repetitive intergenic consensus (ERIC)-PCR. Vet. Microbiol. 89 (4), 323-328.

25. Siqueira, A.K.; Ribeiro, M.G.; Salerno, T.; Takahira, R.K.; Lopes, M.D.; Prestes, N.C.; Silva, A.V. (2008). Perfil de sensibilidade e multirresistência em linhagens de Escherichia coli isoladas de infecção do trato urinário, de piometra e de fezes de cães. Arq. Bras. Med. Vet. Zootec. 601263-1266.

26. Siqueira, A.K.; Ribeiro, M.G.; Leite, D.d.S.; Tiba, M.R.; Moura, C.d.; Lopes, M.D.; Prestes, N.C.; Salerno, T.; Silva, A.V.d. (2009). Virulence factors in Escherichia coli strains isolated from urinary tract infection and pyometra cases and from feces of healthy dogs. Res. Vet. Sci. 86 (2), 206-210.
27. Versalovic, J.; Koeuth, T.; Lupski, R. (1991). Distribution of repetitive DNA sequences in eubacteria and application to finerpriting of bacterial enomes. Nucl. Acids Res. 19 (24), 6823-6831.

28. von Sydow, A.C.M.D.G.; Coggan, J.A.; Moreno, A.M.; Melville, P.A.; Benites, N.R. (2006). Ocorrência de fatores de virulência em estirpes de Escherichia coli isoladas de fezes de cães errantes. Arq. Inst. Biol. (Sao Paulo) 73 (4), 401-407.

29. Wani, S.A.; Bhat, M.A.; Samanta, I.; Nishikawa, Y.; Buchh, A.S. (2003). Isolation and characterization of Shiga toxin-producing Escherichia coli (STEC) and enteropathogenic Escherichia coli (EPEC) from calves and lambs with diarrhoea in India. Lett. Appl. Microbiol. 37 (2), 121-126.

30. Yuri, K.; Nakata, K.; Katae, H.; Yamamoto, S.; Hasegawa, A. (1998). Distribution of Uropathogenic Virulence Factors among Escherichia coli Strains Isolated from Dogs and Cats. J. Vet. Med. Sci. 60 (3), 287-290. 